\title{
Does the pre-operative buccal soft tissue level at teeth or gingival phenotype dictate the aesthetic outcome after flapless immediate implant placement and provisionalization? Analysis of a prospective clinical case series
}

\author{
Edith Groenendijk ${ }^{1 *}$, Ewald Maria Bronkhorst ${ }^{2}$ and Gert Jacobus Meijer ${ }^{3}$
}

\begin{abstract}
Background: Immediate implant placement (IIP) often is related to mid-buccal recession in literature. To draw conclusions about the behavior of the soft tissues following IIP, pre-operative aesthetic measurements have to be taken into account. The aim of analysis of these prospective clinical case series data was to elucidate whether the pre-operative buccal soft tissue level (STL) or gingival phenotype influence the 1-year pink aesthetic outcome after performing flapless immediate implant placement and provisionalization (FIIPP) maxillary incisor cases.

Materials and methods: In 97 patients, a maxillary incisor was replaced performing FIIPP. STL and phenotype were analyzed on light-photographs made pre-operatively $\left(T^{0}\right)$, direct post-operatively $\left(T^{1}\right)$, after placement of the permanent crown $\left(T^{2}\right)$, and 1 year post-operatively $\left(T^{3}\right)$. To investigate if a pre-operative buccal soft tissue deficiency or excess influenced the total pink esthetic score (total-PES) per patient at $\mathrm{T}^{3}$, PES-3 was modified by adding a minus ("-") or plus ("+") in case of a STL-deficiency or excess, respectively.

Results: Pre-operatively, 40\% of the cases showed a mid-buccal recession (STL-deficiency), 19\% STL-excess, while in $41 \%$ an equal level in comparison with the contra-lateral tooth was observed (STL-neutral). One year post-operatively, 79\% (31/39) of the recession cases showed soft tissue gain, while STL-excess cases showed the highest rate of soft tissue reduction $(94 \% ; 17 / 18)$. This resulted in a decrease of soft tissue recessions and excesses (to $26 \%$ and $4 \%$, respectively), and an increase of ideal STL (PES-3-score 2) to 70\%. The 1-year aesthetic outcome was not statistically different $\left(p=0.577\right.$ ) between patients with a pre-operative soft tissue recession (mean $\mathrm{T}^{3}$ total-PES $=12.18$ ) or STL excess (mean $T^{3}$ total-PES $\left.=11.94\right)$. Of the total population, 71 patients with a thin, and 26 with a thick phenotype were evaluated. No statistical difference $(p=0.08)$ was present in aesthetic outcome between the two phenotypes (thin mean $\mathrm{T}^{3}$ total-PES $=12.30$, thick mean $\mathrm{T}^{3}$ total-PES $=11.65$ ).
\end{abstract}

Conclusion: Regardless of phenotype, preoperative soft tissue recession, or excess, comparable high aesthetic outcomes were achieved 1 year post-operatively.

\footnotetext{
* Correspondence: edith@implantologiedenhaag.nl

${ }^{1}$ Clinique Implantologie Den Haag, Stadhouderslaan 12, 2517 HW Den Haag, The Netherlands

Full list of author information is available at the end of the article
}

\section{Springer Open}

(c) The Author(s). 2021 Open Access This article is licensed under a Creative Commons Attribution 4.0 International License, which permits use, sharing, adaptation, distribution and reproduction in any medium or format, as long as you give appropriate credit to the original author(s) and the source, provide a link to the Creative Commons licence, and indicate if changes were made. The images or other third party material in this article are included in the article's Creative Commons licence, unless indicated otherwise in a credit line to the material. If material is not included in the article's Creative Commons licence and your intended use is not permitted by statutory regulation or exceeds the permitted use, you will need to obtain permission directly from the copyright holder. To view a copy of this licence, visit http://creativecommons.org/licenses/by/4.0/. 
Trial registration: Ethical approval was obtained and registered on 20 October 2015 (NTR5583/NL4170).

Keywords: Immediate implant placement and provisionalization, Immediate restoration, Aesthetic outcome, Modified pink esthetic score, Soft tissue level, Mid-buccal recession, Pink aesthetic score, Flapless implant surgery, IIP, IIPP

\section{Background}

The risk of a poor pink aesthetic outcome of immediately placed implants often is related to mid-buccal recession in literature [1-3]. Surgical and restorative approaches, as also implant position, are pivotal in achieving an optimal aesthetic outcome, particularly on the point of the mid-buccal soft tissue level.

Hardly any of the studies on the field of the aesthetic outcome after implant therapy are comparable with each other considering heterogeneity of treatment protocols, implant position, materials, and aesthetic scores used. To evaluate the soft tissues around dental implants, in 2005, the Pink Esthetic Score (PES) was introduced by Fürhauser et al. [4]; soft tissues are judged using seven criteria which each can be scored by 0,1 , or 2 . Therefore, the total pink aesthetic score (total-PES) ranges from 0 to 14 (total-PES ${ }_{1-14}$ ). This method is applied in many researches [5-15] and generally preferred over the simplified-PES, introduced by Belser et al. [16]. This latter was launched in favor of 'ease of use and understanding' by varying the total-PES score between 1 and 10 (total-PES $1-10$ ). For this goal, important information is sacrificed by merging the original criteria "alveolar deficiency," "soft tissue color," and "soft tissue texture."

To draw conclusions about the behavior of the soft tissues following IIP, pre-operative aesthetic measurements have to be taken into account. In our prospective cases series, we reported a high over-all aesthetic outcome (total-PES = 12.1) 1 year after FIIPP [15]. This analysis elucidates whether the pre-operative buccal soft tissue level (STL) or gingival phenotype influences the 1-year pink aesthetic outcome after performing FIIPP in single tooth maxillary incisor cases.

\section{Material and methods}

In a prospective clinical case series, 100 consecutive patients were treated with flapless immediate implant placement and provisionalization (FIIPP), due to a failing maxillary incisor. The CARE reporting guidelines were used [17]. Inclusion criteria were (1) presence of one failing single maxillary incisor in between two neighboring healthy teeth, (2) sufficient occlusal support, (3) absence of periodontal disease, (4) absence of bruxism, (5) existence of an adequate bone height at the apical area of the socket (at least $5 \mathrm{~mm}$ ) to allow primary implant stability. Intact sockets, as also sockets with a peri-apical bone defect or a crestal bone defect not exceeding $5 \mathrm{~mm}$, were included. Reasons for extraction comprised crown or root fracture, root resorption, caries, and persisting endodontic pathology. Exclusion criteria were (1) smoking habits exceeding more than 10 units a day, (2) pregnancy, (3) bone diseases or a history of irradiation, (4) ASA III or higher. Both surgical and restorative procedures were performed following a standardized protocol $[13,15]$.

\section{Pink aesthetic outcome and gingival phenotype}

Both the implant and contra-lateral site were photographed in a standardized way [18] at different time points; pre-operatively $\left(\mathrm{T}^{0}\right), 7-14$ days post-operatively $\left(\mathrm{T}^{1}\right)$, direct after placement of the permanent crown $\left(\mathrm{T}^{2}\right)$, and 1 year post-operatively $\left(\mathrm{T}^{3}\right)$. On each time point, two light photographs were taken: one perpendicular to the mid-buccal of the tooth arch, and one perpendicular to the implant site. Before examination, the light photographs were placed in a digital format. Evaluation of the pink aesthetic outcome was executed as described by Fürhauser et al. [4], by two blinded examiners, who were not involved in the patient treatments. The same was true for the phenotype analysis. The inter-examiner reliability showed an intra-class correlation coefficient (ICC) of 0.979 for the PES.

\section{STL measurements}

For these measurements, light photographs perpendicular to the tooth arch at $\mathrm{T}^{0}, \mathrm{~T}^{1}, \mathrm{~T}^{2}$, and $\mathrm{T}^{3}$ were used and placed into a digital format. Reference lines were drawn through, gingival margin of the contra-lateral incisor, incisal edge of contra-lateral incisor, and distal from the central and lateral incisors. The gingival margin of the failing tooth at $\mathrm{T}^{0}$ was drawn in blue as a reference at different time points.

In order to enlighten if the pre-operative buccal STL influenced the total-PES per patient at $\mathrm{T}^{3}$, the PES-3 of the total pink aesthetic score (PES) [4] was modified. The original PES-3 index by Fürhauser et al. (2005) only describes a discrepancy in the STL. Whether this is positive (excess) or negative (deficiency) remains unclear. For instance, a site can show an excess of soft tissue of 1-2 mm pre-operatively and show a deficiency of $1-2$ $\mathrm{mm} 1$ year post-operatively; however, in both situations, the PES-3 score is 1 . Our proposal is to change the PES3 into the modified PES-3 (mPES-3); a minus ("-") is added to the score when a STL deficiency is observed, and a plus ("+") if an excess of soft tissue is present. The 
Table 1 Modified PES-3 (mPES-3); in case of a deficiency, a minus sign, and in case of a surplus, a plus sign is added behind the original PES-3 score

\begin{tabular}{|c|c|c|c|c|}
\hline \multicolumn{5}{|c|}{$\begin{array}{l}\text { Modified PES-3 (mPES-3): level of soft-tissue margin versus refer- } \\
\text { ence tooth }\end{array}$} \\
\hline $0-$ & $1-$ & 2 & $1+$ & $0+$ \\
\hline $\begin{array}{l}\text { Major } \\
\text { deficiency } \\
>2 \mathrm{~mm}\end{array}$ & $\begin{array}{l}\text { Minor } \\
\text { deficiency } \\
1-2 \mathrm{~mm}\end{array}$ & $\begin{array}{l}\text { No } \\
\text { discrepancy } \\
>1 \mathrm{~mm}\end{array}$ & $\begin{array}{l}\text { Minor } \\
\text { surplus } \\
1-2 \mathrm{~mm}\end{array}$ & $\begin{array}{l}\text { Major } \\
\text { surplus } \\
>2 \mathrm{~mm}\end{array}$ \\
\hline
\end{tabular}

exact method is presented in Table 1 . In case of STLdeficiency, a "minus" sign to PES-3-score was added, and in case of a STL-excess, a "plus" sign. As reference, always the contra-lateral reference tooth was used.

\section{Statistical methods}

Total-PES at different time points $\mathrm{T}^{0}, \mathrm{~T}^{1}, \mathrm{~T}^{2}$, and $\mathrm{T}^{3}$ of patients with a pre-operative soft tissue recession or excess, as well as biotype were compared and tested on significant difference using Levene's test for equality of variances and t test for equality of means. Statistical significance was defined as $\mathrm{p}=0.05$.

\section{Results}

Of the 100 included patients, 97 were available for evaluation; 1 was excluded because the implant site was traumatized; the already installed implant was replaced by a new one. Another patient withdrew because of relocation. Of the third patient, the light photos were missing at $\mathrm{T}^{0}$. The remaining 97 patients consisted of 56 females and 41 males with a mean age of 46 years (range 17-80 years). Unfortunately, eight light photos were missing at $\mathrm{T}^{1}$, and seven at $\mathrm{T}^{2}$.

\section{STL measurements}

Examples of 3 cases per pre-operative STL and their modified PES-3 scores (mPES-3) at $\mathrm{T}^{0} / \mathrm{T}^{3}$ are shown in Fig. 1. Distribution of cases per STL-group (mPES-3 =0 $-, 1-, 2,1+, 0+)$ per timepoint is shown in Fig. 2.
Pre-operatively, $40 \%$ of the cases showed a mid-buccal recession (STL-deficiency), 19\% STL-excess, while in $41 \%$ an equal level in comparison with the contra-lateral tooth was observed (STL-neutral). One year postoperatively, 79\% (31/39) of the recession cases showed soft tissue gain, while STL-excess cases showed the highest rate of soft tissue reduction $(94 \% ; 17 / 18)$. This resulted in a decrease of soft tissue recessions and excesses (to $26 \%$ and $4 \%$, respectively), and an increase of ideal STL (PES-3 = 2) to 70\%.

Comparing 1-year pink aesthetic outcome of cases with a baseline STL-deficiency (mean $\mathrm{T}^{3}$ total-PES = 12.18) or STL-excess (mean $\mathrm{T}^{3}$ total-PES $=11.94$ ), there was no statistical difference $(\mathrm{p}=0.577$ ) found (Table 2 ). Thus, whether a pre-operative STL-deficiency or STLexcess was present, it did not affect the pink aesthetic outcome 1 year post-operatively.

\section{Gingival phenotype}

Of the total population, 71 patients with a thin phenotype and 26 with a thick phenotype were found (Table 3). There was no statistical difference $(p=0.079)$ in aesthetic outcome found between patients with a thin (mean $\mathrm{T}^{3}$ total-PES $=12.30$ ) or thick phenotype (mean $\mathrm{T}^{3}$ total-PES $=11.65)$.

\section{Discussion}

A difference in pink aesthetic outcome was expected between cases showing a pre-operative STL-excess, a preoperative STL-neutral, or pre-operative STL-deficiency. Especially for the latter, a lower total-PES was expected. However, the contrary appeared true; after performing FIIPP, also for the STL-deficiency cases a not significant different high total-PES score was noted. As such, the pre-operative STL at teeth did not influence the overall pink aesthetic outcome 1 year post-operatively.

In cases with a pre-operative excess of soft tissue comparing to the contra-lateral incisor, reduction of soft tissue height is required. In 15 cases, the desired STL reduction was reached to level up with the contra-lateral

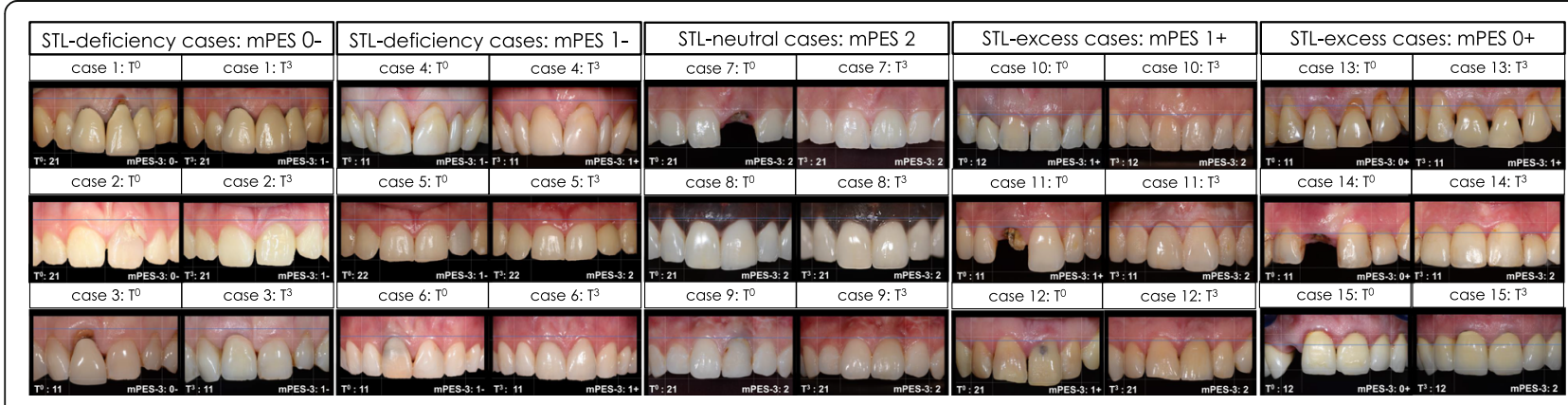

Fig. 1 Three examples of cases with comparable pre-operative soft tissue level (STL) and their STL at $T^{3}$; STL-deficiency $>2 \mathrm{~mm}$ ( $\mathrm{mPES}=0-$ ), STLdeficiency 1-2 mm (mPES = 1-), STL-neutral (mPES $=2)$, STL-excess ( $\mathrm{mPES}=1+$ ), and STL-excess $(\mathrm{mPES}=0+)$ 


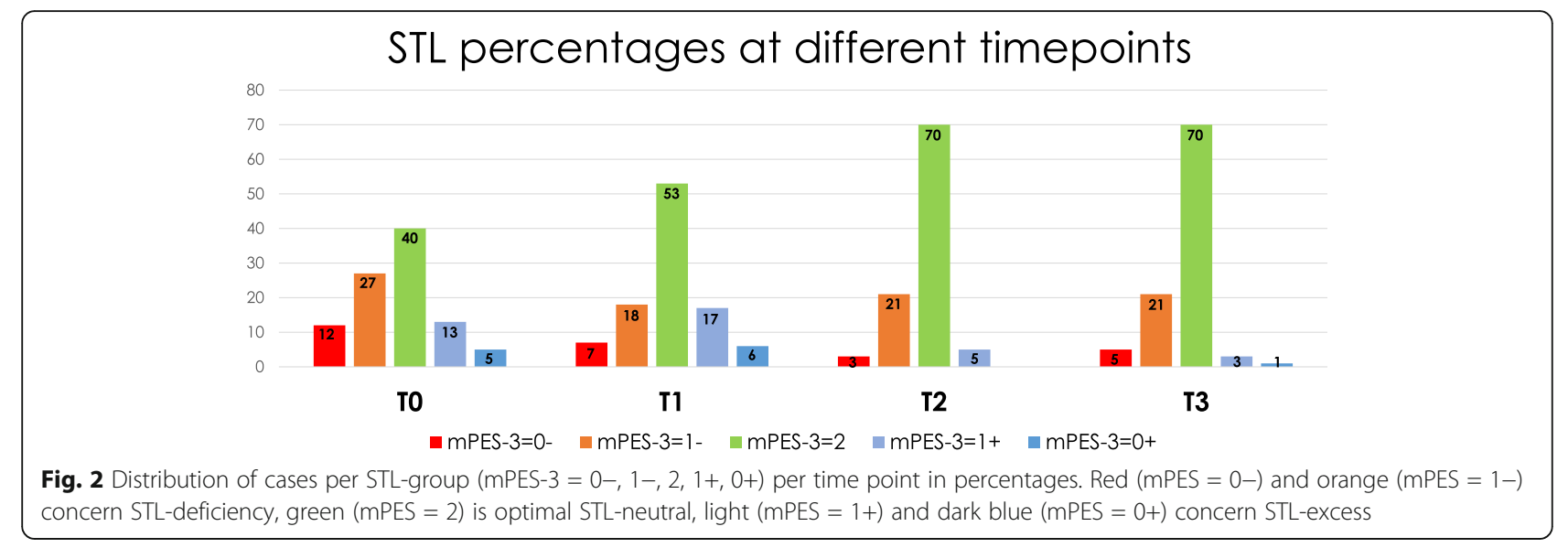

tooth. This was obtained by less filling of the socket with bone substitute and/or by lateral pressure of the abutment/crown onto the soft tissue during placement. It has to be taken into account that the soft tissues after socket-grafting by application of a bone substitute are less resilient. That is probably the reason that in one, case the surplus of soft tissue remained. In the two recession cases of the "excess" group (from mPES- $3 \mathrm{~T}^{0}=$ $1+$ to $\mathrm{mPES}-3 \mathrm{~T}^{3}=1-$ ), probably too much lateral pressure of the supra-structure onto the tissues caused a undesired soft tissue deficiency. Despite of this, in 100\% of the cases, the same or better PES-3 score was achieved. Appliance of the mPES-3 clarified what really happened with the STL.

Cases starting with a STL-neutral seemed to be most challenging to treat. In this group, the pre-operative STL is already optimal, the soft tissues have only to be preserved, however, not over- or under-contoured. A slight change of the soft tissue will result in a lesser aesthetic outcome. The post-operative recessions probably are a result of bone-substitute leakage due to post-operative bleeding, or placement of a too bulky permanent abutment causing pressure onto the surrounding hard- and soft tissues.

Surprisingly, STL gain occurred in cases were preoperatively a STL-deficiency (recession) was present. This is in confirmation with the findings of Noelken et al. [19]. They performed immediate implant placement and provisionalization (IIPP) on a single maxillary tooth with a pre-operative recession in 26 patients, of which 13 were treated with a connective tissue graft, and 13 without such graft. After a mean follow-up period of 45 months, recessions were significantly reduced in both groups. In another study, in which IIPP in intact sockets and defect sockets was compared, similar data on the field of total-PES score were presented [20]. In both intact extraction sockets, as well as in alveoli with buccal bone defects, IIPP rendered similar outcomes with

Table 2 Comparison of mean total-PES for all points in time, based on surplus, or deficiency of STL at $\mathrm{T}^{0}$. Equal variances were assumed

\begin{tabular}{|c|c|c|c|c|c|c|c|c|}
\hline \multicolumn{5}{|c|}{ Group statistics } & \multicolumn{4}{|c|}{$T$ test for equality of means } \\
\hline & & \multirow[t]{2}{*}{$\mathbf{N}$} & \multirow[t]{2}{*}{ Mean } & \multirow[t]{2}{*}{ SD } & \multirow{2}{*}{$\begin{array}{l}p \\
\text { value } \\
\text { (2- } \\
\text { tailed) }\end{array}$} & \multirow{2}{*}{$\begin{array}{l}\text { Mean } \\
\text { difference }\end{array}$} & \multicolumn{2}{|c|}{$95 \%$ Confidence interval of the difference } \\
\hline & & & & & & & Lower & Upper \\
\hline \multirow[t]{2}{*}{ Total-PES T ${ }^{0}$} & STL deficiency at $\mathrm{T}^{0}$ & 39 & 9.23 & 2.64 & 0.946 & -0.05 & -1.44 & 1.35 \\
\hline & STL excess at $\mathrm{T}^{0}$ & 18 & 9.28 & 1.93 & & & & \\
\hline \multirow[t]{2}{*}{ Total-PES T ${ }^{1}$} & STL deficiency at $\mathrm{T}^{0}$ & 35 & 10.54 & 2.36 & 0.442 & 0.48 & -0.77 & 1.74 \\
\hline & STL excess at $T^{0}$ & 17 & 10.06 & 1.48 & & & & \\
\hline \multirow[t]{2}{*}{ Total-PES T² } & STL deficiency at $\mathrm{T}^{0}$ & 37 & 11.62 & 1.38 & 0.883 & -0.07 & -0.96 & 0.83 \\
\hline & STL excess at $T^{0}$ & 16 & 11.69 & 1.70 & & & & \\
\hline \multirow[t]{2}{*}{ Total-PES T ${ }^{3}$} & STL deficiency at $\mathrm{T}^{0}$ & 39 & 12.18 & 1.49 & 0.577 & 0.24 & -0.60 & 1.07 \\
\hline & STL excess at $\mathrm{T}^{0}$ & 18 & 11.94 & 1.43 & & & & \\
\hline
\end{tabular}


Table 3 Effect of biotype on pink aesthetic outcome 1 year post-operatively

\begin{tabular}{|c|c|c|c|c|c|c|c|c|}
\hline \multicolumn{5}{|c|}{ Group statistics } & \multicolumn{4}{|c|}{$T$ test for equality of means } \\
\hline & \multirow[t]{2}{*}{ Biotype } & \multirow[t]{2}{*}{$\mathbf{N}$} & \multirow[t]{2}{*}{ Mean } & \multirow{2}{*}{$\begin{array}{l}\text { SE } \\
\text { mean }\end{array}$} & \multirow{2}{*}{$\begin{array}{l}p \\
\text { value } \\
\text { (2- } \\
\text { tailed) }\end{array}$} & \multirow{2}{*}{$\begin{array}{l}\text { Mean } \\
\text { difference }\end{array}$} & \multicolumn{2}{|c|}{ 95\% Confidence interval of the difference } \\
\hline & & & & & & & Lower & Upper \\
\hline \multirow[t]{2}{*}{ Total-PES T ${ }^{3}$} & $0=$ thin & 71 & 12.30 & 0.162 & 0.079 & 0.642 & -0.076 & 1.36 \\
\hline & $1=$ thick & 26 & 11.65 & 0.404 & & & & \\
\hline
\end{tabular}

regard to total-PES, height of the buccal gingival margin, and peri-implant bone level after 1 year. Although their treatment protocol is different, these authors corroborate that recession sites can improve after IIPP. Multiple other authors already stressed that, due to performing ridge preservation, a gain in alveolar height was observed $[21,22]$. This implicates that in our study, ridge preservation was not disturbed by immediate implant placement.

It is unclear how our results align with other IIPP or early and delayed placement protocol studies. In 2015, Schropp and Isodor [23] published that 1 to 1.5 years after performing early or delayed implant placement, less than $60 \%$ of the cases showed an appropriate crown length, thus STL-level. In addition, they stated that early placed implants tended to be superior to delayed-placed implants with respect to STL level. So cautiously, it can be stated that performing FIIPP conform this standardized protocol $[13,15]$ and shows better results at the point of soft tissue level than early or delayed protocols. Further research is necessary to confirm or decline these assumptions.

A thin gingival phenotype did not affect the pink aesthetic outcome. An explanation may be that by implants' palatal positioning, a thick hard tissue crest is created.

A shortcoming of this study was that the STL was not measured in millimeter, but that a classification was used to monitor the STL, such as the PES. Unexpected was the high number of cases with a pre-operative STLdeficiency; indeed, it was possible to gain soft tissue without applying a soft tissue graft. Within the limitations of this prospective case series, we may conclude that patients with a small pre-operative STL-deficiency or STL-excess showed the same high aesthetic outcome (total-PES) as compared to cases with a pre-operative STL-neutral, 1-year post-operatively. Pre-operative midbuccal recession, as well as STL-excess cases, tended to improve, while the cases with a neutral pre-operative STL were the most difficult to obtain.

\footnotetext{
Abbreviations

IIP: Immediate implant placement; STL: Soft tissue level; FIIPP: Flapless immediate implant placement and provisionalization; PES: Pink aesthetic score; mPES: Modified pink aesthetic score
}

\begin{abstract}
Acknowledgements
We are very grateful to the different treatment centers who collected the crucial data for us:

Referral Clinic: Tjongerjans: Dr. Wouter Kalk. Dental Center: Houttuinen: Dr. Bart Polder. Referral Clinic: Implantologie Den Haag: Dr. MSc Edith

Groenendijk. Referral Clinic: Staas \& Bergmans: Dr. Tristan Staas. Referral

Clinic: XQ Dent: Dr. Jeroen Pepplinkhuizen. UMCG Groningen: Prof. Dr. Gerry Raghoebar.
\end{abstract}

\section{Authors' contributions}

E.G. conceived the ideas, did acquisition, collected, analyzed and interpreted the data, and drafted the paper as first author. E.M.B. statistically analyzed the data. G.J.M. critical revised and guided the scientific writing. All authors read and approved the final manuscript.

\section{Funding}

Nobel Biocare provided a website to collect the data and a research manager in order to control if the methodology was followed correctly.

\section{Availability of data and materials}

The datasets used and/or analyzed during the current study are available from the corresponding author on reasonable request.

\section{Declarations}

\section{Ethics approval and consent to participate}

Ethical approval was obtained from the Ethics Committee of the Radboud University Medical Center Nijmegen (2014/157). The study was registered in the Dutch Trial Register (NTR) on 20 October 2015 (NTR5583/NL4170). All patients gave approval for participation in the study.

\section{Consent for publication}

All patients gave written informed consent for publication.

\section{Competing interests}

The authors declare that they have no competing interests.

\section{Author details}

${ }^{1}$ Clinique Implantologie Den Haag, Stadhouderslaan 12, 2517 HW Den Haag, The Netherlands. ${ }^{2}$ Department of Preventive and Curative Dentistry, Radboudumc, Nijmegen, The Netherlands. ${ }^{3}$ Department of Oral and Maxillofacial Surgery, Radboudumc, Nijmegen, The Netherlands.

Received: 12 February 2021 Accepted: 16 June 2021

Published online: 27 August 2021

\section{References}

1. Chen ST, Buser D. Clinical and esthetic outcomes of implants placed in postextraction sites. Int J Oral Maxillofac Implants. 2009;24(Suppl):186-217 PMID: 19885446.

2. Cosyn J, Hooghe N, De Bruyn H. A systematic review on the frequency of advanced recession following single immediate implant treatment. J Clin Periodontol. 2012;39(6):582-9. https://doi.org/10.1111/j.1600-051X.2012.01888.x.

3. Chen ST, Buser D. Esthetic outcomes following immediate and early implant placement in the anterior maxilla - A systematic review. Int J Oral Maxillofac Implants. 2014;29(Suppl):186-215. https://doi.org/10.11607/jomi.2014.suppl.g3.3.

4. Fürhauser R, Florescu D, Benesch $T$, Haas R, Mailath G, Watzek G. Evaluation of soft tissue around single-tooth implant crowns: the pink esthetic score. 
Clin Oral Implants Res. 2005;16(6):639-44. https://doi.org/10.1111/j.16000501.2005.01193.X.

5. Juodzbalys G, Wang HL. Soft and hard tissue assessment of immediate implant placement: a case series. Clin Oral Implants Res. 2007;18(2):237-43. https://doi.org/10.1111/j.1600-0501.2006.01312.x.

6. Chen ST, Darby IB, Reynolds EC, Clement JG. Immediate implant placement postextraction without flap elevation. J Periodontol. 2009;80:163-72. https:// doi.org/10.1902/jop.2009.080243.

7. Cosyn NJ, Eghbali A, de Bruyn H, Collys K, Cleymaet R, de Rouck T. Immediate single-tooth implants in the anterior maxilla: 3 -year results of a case series on hard and soft tissue response and aesthetics. J Clin Periodontol. 2011;38(8): 746-53. https://doi.org/10.1111/j.1600-051X.2011.01748.x.

8. Noelken R, Kunkel M, Wagner W. Immediate implant placement and provisionalization after long-axis root fracture and complete loss of the facial bony lamella. Int J Periodontics Restorative Dent. 2011;31:175-83 PMID: 21491017

9. Raes F, Cosyn J, Crommelinck E, Coessens P, de Bruyn H. Immediate and conventional single implant treatment in the anterior maxilla: 1-year results of a case series on hard and soft tissue response and aesthetics. J Clin Periodontol. 2011;38(4): 385-94. https:/doi.org/10.1111/j.1600-051X.2010.01687X.

10. Noelken $\mathrm{R}$, Kunkel M, Jung BA, Wagner W. Immediate nonfunctional loading of NobelPerfect implants in the anterior dental arch in private practice-5year data. Clin Implant Dent Relat Res. 2014;16(1):21-31. https://doi.org/1 0.1111/j.1708-8208.2012.00449.x.

11. Cosyn J, De Bruyn H, Cleymaet R. Soft tissue preservation and pink aesthetics around single immediate implant restorations: a 1-year prospective study. Clin Implant Dent Relat Res. 2013;15(6):847-57. https:// doi.org/10.1111/j.1708-8208.2012.00448.x.

12. Cosyn J, Eghbali A, Hermans A, Vervaeke S, de Bruyn H, Cleymaet R. A 5year prospective study on single immediate implants in the aesthetic zone. J Clin Periodontol. 2016;43(8):702-9. https://doi.org/10.1111/jcpe.12571.

13. Groenendijk E, Staas TA, Graauwmans FEJ, Bronkhorst EM, Verhamme L, Maal T, et al. Immediate implant placement: the fate of the buccal crest. A retrospective Cone Beam Computed Tomography Study. Int J Oral Maxillofac Surg. 2017;46:1600-6. https://doi.org/10.1016/j.jom.2017.06.026.

14. Raes S, Eghbali A, Chappuis V, Raes F, de Bruyn H, Cosyn J. A long-term prospective cohort study on immediately restored single implants installed in extraction sockets and healed ridges: $\mathrm{CBCT}$ analyses, soft tissue alternations, aesthetic ratings and patient-reported outcomes. Clin Implant Dent Rel Res. 2018;20(4):522-30. https://doi.org/10.1111/cid.12613.

15. Groenendijk E, Staas TA, Bronkhorst EM, Raghoebar GM, Meijer GJ. Immediate implant placement and provisionalization: aesthetic outcome 1 year after implant placement. A Prospective Clinical Multicenter Study. Clin Implant Dent Relat Res. 2020;1:1-8. https://doi.org/10.1111/cid.12883.

16. Belser UC, Grutter L, Vailati F, Bornstein MM, Weber HP, Buser D. Outcome evaluation of early placed maxillary anterior single-tooth implants using objective esthetic criteria: a cross-sectional, retrospective study in 45 patients with a 2- to 4-year follow-up using pink and white esthetic scores. J Periodontol. 2009;80:140-51. https://doi.org/10.1902/jop.2009.080435.

17. Gagnier JJ, Kienle G, Altman DG, Moher D, Sox H, Riley D; the CARE Group. The CARE Guidelines: Consensus-based Clinical Case Reporting Guideline Development.

18. van Oort D, Van Loghum BS. Digitale mondfotografie: Een praktische handleiding; 2009. p. 149.

19. Noelken R, Moergel M, Paush T, Kunkel M, Wagner W. Clinical and esthetic outcome with immediate insertion and provisionalization with and without connective tissue grafting in presence of mucogingival recessions: a retrospective analysis with follow-up between 1 and 8 years. Clin Implant Dent Rel Res. 2018;20:285-93. https://doi.org/10.1111/cid.12595.

20. Pohl V, Fürhauser I, Haas R, Pohl S. Gingival recession behavior with immediate implant placement in the anterior maxilla with buccal dehiscence without additional augmentation - a pilot study. Clin Oral Investig. 2020:1-10. https://doi.org/10.1007/s00784-019-03176-5.

21. lasella JM, Greenwell H, Miller RL, et al. Ridge preservation with freeze-dried bone allograft and a collagen membrane compared to extraction alone for implant site development: a clinical and histologic study in humans. J Periodontol. 2003;74(7):990-9. https://doi.org/10.1902/jop.2003.74.7.990.

22. Vance GS, Greenwell H, Miller RL, Hill M, Johnston H, Scheetz JP. Comparison of an allograft in an experimental putty carrier and bovinederived xenograft used in ridge preservation: a clinical and histologic study in humans. Int J Oral Maxillofac Implants. 2004;19:491-7 PMID: 15346745.
23. Schropp L, Isidor F. Papilla dimension and soft tissue level after early vs. delayed placement of single-tooth implants: 10-year results from a randomized controlled clinical trial. Clin Oral Implants Res. 2015;26(3):27886. https://doi.org/10.1111/clr.12489.

\section{Publisher's Note}

Springer Nature remains neutral with regard to jurisdictional claims in published maps and institutional affiliations.

\section{Submit your manuscript to a SpringerOpen ${ }^{\circ}$ journal and benefit from:}

- Convenient online submission

- Rigorous peer review

- Open access: articles freely available online

High visibility within the field

- Retaining the copyright to your article

Submit your next manuscript at $\boldsymbol{\nabla}$ springeropen.com 